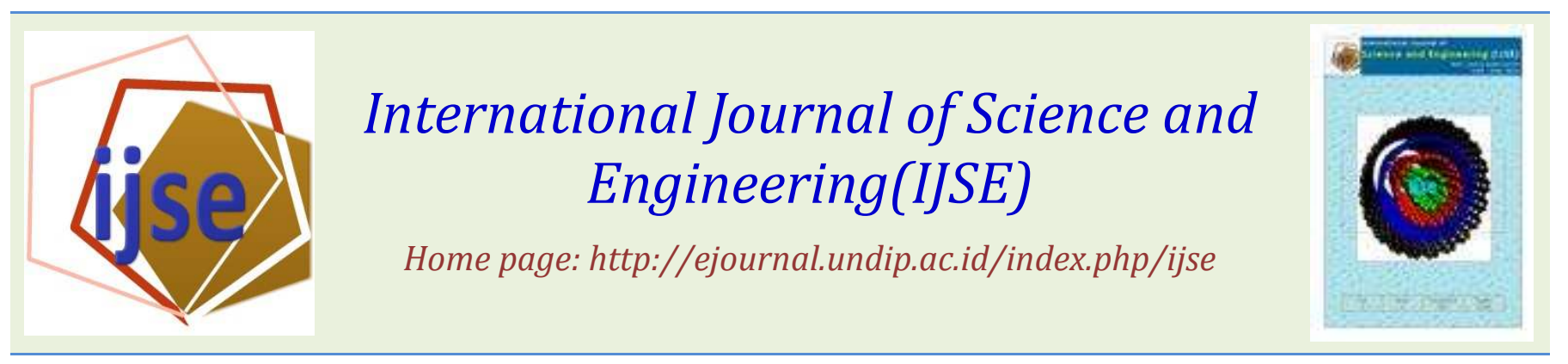

\title{
Drying of Rosella (Hibiscus sabdariffa) Flower Petals using Solar Dryer with Double Glass Cover Collector
}

\author{
Tjukup Marnoto $^{\#)}$, Endang Sulistyowati ${ }^{\#)}$, Budiyastuti, P. ${ }^{\# \#)}$, Sumarwoto, PS $^{\# \#)}$, M. Syahri ${ }^{\#)}$, Bambang Sugiarto ${ }^{\#)}$. \\ Yusuf Hanafi ${ }^{\#)}$, Girman ${ }^{\#)}$, Kristianingrum ${ }^{\#)}$. \\ \#)Department of Chemical Engineering, Faculty of Industrial Technology \\ \#\#)Department of Agrotechnology, Faculty of Agriculture \\ UPN "Veteran" Yogyakarta \\ SWK Street No.104 Lingkarutara Condongcatur Yogyakarta 55283.
}

Email: tjukup@upnyk.ac.id.

\begin{abstract}
Chemical ingredients in rosella petals are very beneficial for health. Rosella petals needed to be drained for storage and packing purpose. The traditional drying takes 5 days and less healthy. Solar dryer technology can speed up the drying process and protect materials from dust contamination. Solar dryer with double glass covered collector has been designed and made for drying of agricultural products such as rosella flowers. Rosella petals as much as 2300 grams with initial moisture content of $90.84 \%$ be dried with this dryer until the moisture content of $7.67 \%$ takes only 2 days, although the weather was less sunny. The temperature in the drying chamber was not more than $50^{\circ} \mathrm{C}$, so it was good for drying groceries, not damaging chemical ingredients. The relative humidity in the space dryeris was about $40 \%$ and it was still relative low. Drying rate and drying performance was expressed by the efficiency and Specific Moisture Evaporation Rate ( SMER ) were influenced by water content of the dried material and weather. Daily efficiency at the first and the second day: $14.931 \%$ and 5.78\%, while the daily SMER on the first and the second day: 0.222 and 0.0256 ( kg / kWh )..
\end{abstract}

Keywords-Drying, Rosella, Solar Energy, Solar thermal, Agricultural products

Submission: Sept 17, 2014

Corrected : October 12, 2014

Accepted: October 15, 2014

Doi: 10.12777 /ijse.7.2.150-154

[How to cite this article: Marnoto, T., Sulistyowati, E., Budiyastuti, P., Sumarwoto, P.S., Syahri, M., Sugiarto, B., Hanafi, Y., Girman, Kristianingrum. (2014). Drying of Rosella (Hibiscus sabdariffa) Flower Petals using Solar Dryer with Double Glass Cover Collector, International Journal of Science and Engineering, 7 (2),150-15, Doi: 10.12777/ijse.7.2.150-154]

\section{INTRODUCTION}

Red rosella ( Hibiscussabdariffa) is a plant of the tropics and subtropics bleak regions of India to Malaysia and Indonesia. Rosella petals dark red are thick and juicy, they are part of a plant that can be processed into food products. Rosella flower petals contains of gossypetin, anthocyanin, and glucidehibiscin, which are useful as an antioxidant (especially anthocyanins), prevent cancer, control blood pressure, wage the blood circulation, prevent atherosclerosis and anticarcinogenic (Arroyo et al, 2011). According Sudarmayanti and Yunus, (2011), every $100 \mathrm{~g}$ of rosella petals contains 44 calories, $86.2 \% \mathrm{H}_{2} \mathrm{O}, 1.6 \mathrm{~g}$ protein, $0.1 \mathrm{~g}$ fat, $11.1 \mathrm{~g}$ carbohydrates, $2.5 \mathrm{~g}$ fiber, $1.0 \mathrm{~g}$ ash, $160 \mathrm{mg} \mathrm{Ca}$, $60 \mathrm{mg} \mathrm{P}, 3.8 \mathrm{mg} \mathrm{Fe}, 285 \mathrm{mg}$ of beta carotene equivalent, 0.04 $\mathrm{mg}$ thiamine, $0.6 \mathrm{mg}$ riboflavin, $0.5 \mathrm{mg}$ niacin, and $14 \mathrm{mg}$ ascorbic acid, $7.6 \%$ moisture, $24.0 \%$ protein, $22.3 \%$ fat, $15.3 \%$ fiber, $23.8 \% \mathrm{~N}$ - free extract, $7.0 \%$ ash, $0.3 \% \mathrm{Ca}$, $0.6 \% \mathrm{P}$, and $0.4 \% \mathrm{~S}$. Because the rosella petals are juicy and hygroscopic, then for the purposes of processing and storage they should be drained.

Traditional drying with exposure to direct sunlight, can cause loosing/reducing antioxidant capacity, and it is also relatively take long time (Daniel, et al., 2012). Based on information one of the manufacturer the Rosella petals are in Prambanan Yogyakarta, to get dried Rosella petals with traditional drying takes 5 days. The drying process under the sun is also not hygienic because it is placed in the open place which causes cosmic dust contaminated the petals, which may contains viruses or bacteria. Beside of those, they must be taken and stored as soon as the weather change, it causes the drying takes very slowly. If the drying not perfect, it can lead to mushrooming product then rot. Daniel et al., (2012 ) investigated the drying of rosella flower petals with hot air flowing was about $40^{\circ} \mathrm{C}-80^{\circ} \mathrm{C}$, the air velocity from 0.75 to $2.25 \mathrm{~m} / \mathrm{s}$. Required a heater and air booster, so it needed cost for electrical energy. 
The drying process of a material is a dehydration process of any material that occurs because the complex process of heat and mass transfer. This process depends on external parameters such as temperature, humidity and air flow as well as the material properties of the dried material such as surface characteristics, chemical composition, physical structure, size and shape of the product. The principle of solar dryer technology is to use sunlight to heat the material and also heat the air as a medium dryer. The solar dryer if designed properly will have some advantages that provide a faster drying rate, reduce drying area needed, protected materials from dust, insects, birds and animals.

Classification of solar dryers can be divided by the solar ray contact materials dried and also based media flow dryers. (Sharma, etal., 2009; Jairaj, et al., 2009; Lalit M, et al., 2011). The type solar dryer by sunlight exposure to the product is dried, there are three types:

a) Direct Type is: the dried product is directly exposed to sunlight, so that the product is as absorbing heat from direct sunlight. Hair type straight there are some disadvantages such as slow drying due to sunlight is converted to heat by a waterwheel dried products, some product changes color or taste for products in direct contact with the sun.

b) Indirect Type is: Dried product is not exposed to direct sunlight where the product is exposed to warm air that has been heated by using a collector of solar rays, or heat exchanger. This existing type of the dryer, generally have use separate collector, thus requiring large area and usually used force convection with the help of a blower or fan.

c) Joint Type : Hair merge two principles mentioned above, where the product is exposed to direct sunlight and the media fed simultaneously heated air dryer on the collector simultaneously.

Type Solar Dryer by media flow dryer (air) hits dried product stream there are two groups:

1. Natural circulation is air flow naturally based on temperature differences and the differences in moisture content in the air conditioning. This dryer low operating costs, because it does not require the help of a blower or fan that driven by electrical energy. This dryer is more attractive for use in the developing areas that are no electricity network.

2. Forced circulation is an airflow hits the dried product with the help of resources like push blower or fan is installed to force dryer air flow.

Collector solar dryer with doubles glass lid, including indirect type solar dryer. Collector converts solar energy into heat energy. The heat is used to heat the drying air. With natural air circulation inside the drying chamber, it does not require electrical energy for air flow as well as for heating. Drying of rosella flower petals using a solar dryer with double glass covered collector will improve the quality of dry petals and accelerates drying time. In the evening, when the dryer is not sun-drenched anymore and the rosella petals are rudimentary drying, they are left in the drying chamber to dry again on the next day, until they are perfect dry.

\section{MATERIAL AND METHOD}

\section{1).Materials}

Rosella flower were obtained from farmers in Prambanan village. Rosella flowers were wash with water and dried. The flower petals were cleaned, then they were weighed to get the total weight of rosella petals and some of them were placed separately. After that, both of them were placed in the drying chamber. Beta carotene, anthocyanins, and carbohydrates proximat in rosella petals were analyzed.

\section{2). Instrument}

Solar dryer with double glass covered collector has been designed and fabricated with dimensions: length $120 \mathrm{~cm}$, width $80 \mathrm{~cm}$, height $75 \mathrm{~cm}$ rear, front height $65 \mathrm{~cm}$, where the rack from the bottom $20 \mathrm{~cm}$. Rear door $25 \mathrm{~cm}$ wide by $15 \mathrm{~cm}$ distance from the bottom. The dryer consists of 1). Collector solar rays, which consist of black corrugated plate (black body) to convert light into heat solar energy. In order to heat insulation is given the transparent double cover (glass). 2) drying chamber, 3) dryer rack, 4) rear door 5) air vents. The dryer was classified as indirect type and natural circulation, with a shape like a dryer cabinet

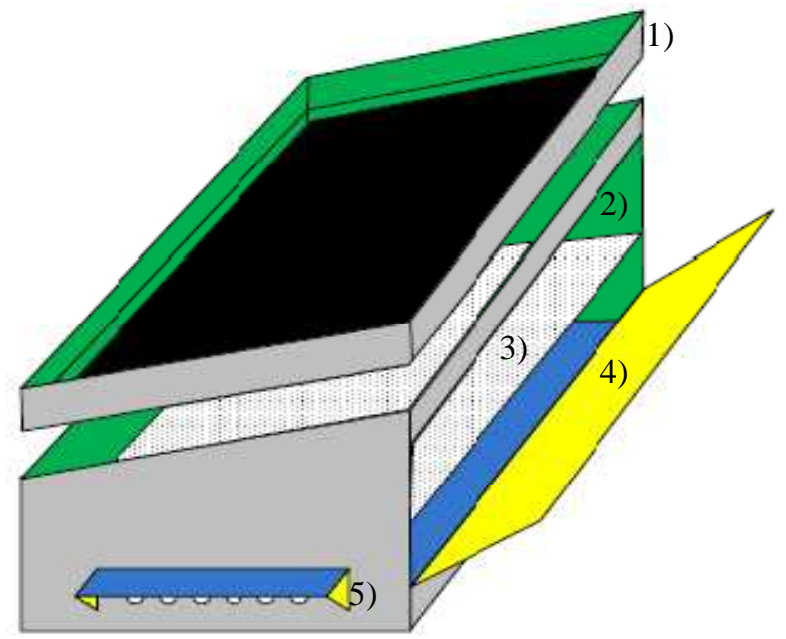

Figure 1 : Sketch of Solar dryer with double glass cover collector

Data collection was carried out with the equipment: Pyranometer to measure the intensity of solar radiation, thermometer, hygrometer, digital scales and interfaces as well as data to the data longer acquisition. The data is taken from sunlight intensity or solar radiation $(\mathrm{G}, \mathrm{W} / \mathrm{m} 2)$, weight of the sample at any time (Wt), top cover temperature (Tp), the black body temperature (TBB), the temperature of the drying chamber $(\mathrm{Tr})$, relative humidity $(\mathrm{RH})$, the data was taken every 5 minute intervals during the drying process. After the drying process is completed/terminated then the dry weight of the sample in the analysis of the sample, using the oven at a temperature of $80^{\circ} \mathrm{C}$, to obtain a constant weight (Wk).

The moisture content at any time during the drying process (Mt) can be calculated on the wet basis or dry basis. The moisture content on wet basis by comparing the weight of the water with a wet weight.

$M_{t}=\frac{M_{t}-M_{k}}{M_{t}}$ 
The moisture ontent on dry basis compared with the dry weight

$\mathbf{M}_{\mathbf{t}}=\frac{\mathbf{M}_{\mathbf{t}}-\mathbf{M}_{\mathbf{k}}}{\mathbf{M}_{\mathbf{k}}}$

Assuming that the moisture content in the drying rack rosella was uniform at all times, it can be calculated by weight of any time $(\mathrm{Wt})$ during drying, by multiplying the ratio by weight of $(\mathrm{Wb})$ and heavy samples (Ws0) initially, and sample weight at anytime (Wst).

$\mathbf{W}_{\mathrm{t}}=\frac{\mathrm{w}_{\mathrm{b}}}{\mathrm{w}_{\mathrm{s} 0}} \cdot \mathbf{W}_{\mathrm{st}}$

According to Singh and Kumar (2012), dryer performance can be demonstrated by the efficiency of solar dryers are expressed as the ratio of the amount of moisture that evaporates and intensity of solar radiation on the collector at any given time.

$\eta_{t}=\frac{\left(W_{t 0}-W_{t}\right) \lambda_{t}}{A \cdot \int_{0}^{t} G \cdot d t}$

Performance of solar dryer can also be experessed by Specific Moisture Evaporation Rate (SMER) (Chua, Chou, Ho, \& Hawlader, 2002). This is defined as the ratio of amount of water that evaporates and energy for drying

SMER $=\frac{\text { Amount of water that evaporates }}{\text { Energy for drying }}\left(\frac{\mathrm{kg}}{\mathrm{kWh}}\right)$

$\operatorname{SMER}=\frac{\left(\mathrm{W}_{\mathrm{t} 0}-\mathrm{W}_{\mathrm{t}}\right)}{\mathrm{A} \cdot \int_{0}^{\mathrm{t}} \mathrm{G} \cdot \mathrm{dt}}\left(\frac{\mathrm{kg}}{\mathrm{kWh}}\right)$

\section{RESULT AND DISCUSSION}

Drying process of rosella flower petals monitored by weighing the sample in the drying chamber, measuring the intensity of the solar rays (G), black plate temperature, ambient temperature and relative humidity dryer, every 5 minutes. The weather when drying process was not bright, which shown intensity of the solar rays were always changing uncertain, so for clarify the data has integrated in to time every 30 minutes, as shown in Figure 2. Which shows the intensity of the solar rays every 5 minute and the results of the integration of 30 minutes.

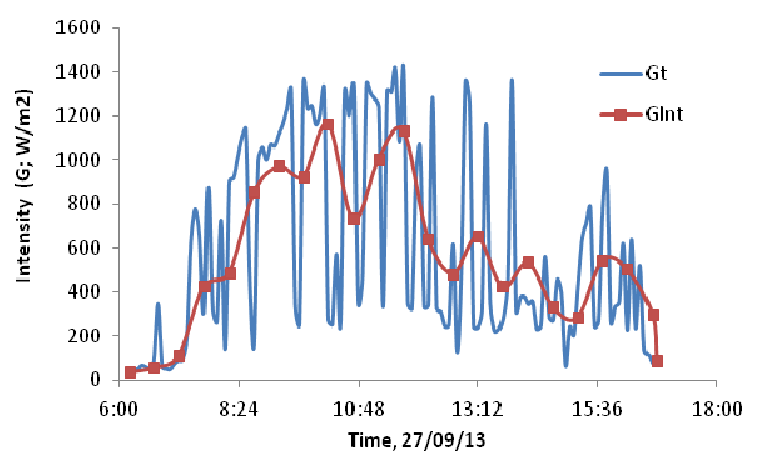

Figure 2: The intensity of solar radiation on 09/27/2013
To achieve the moisture content below $10 \%$ in the rosella flower petals which were dried by using solar dryer,took 2 days. Solar radiation data $(\mathrm{G})$, Relative Humidity inside the drying chamber $(\mathrm{RH})$, temperature drying room (TR) and weight of materials at any time during the drying process is presented in Figure 3 and Figure 4.

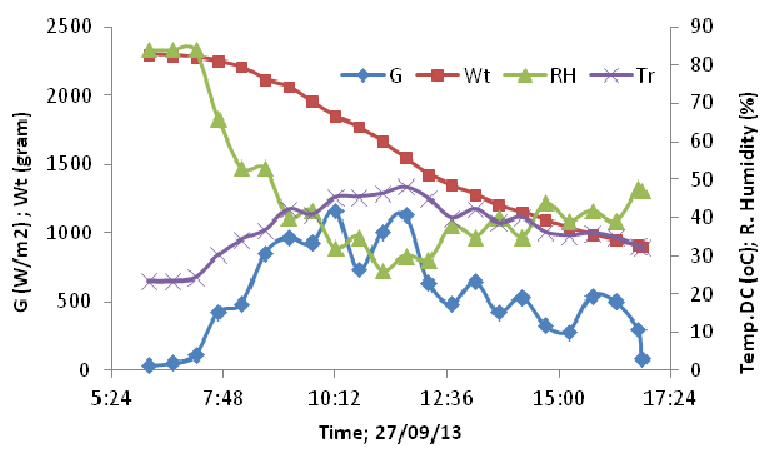

Figure 3: The intensity of the solar radiation, materials Weight, Temperature and Relative Humidity drying chamber, at any drying time.

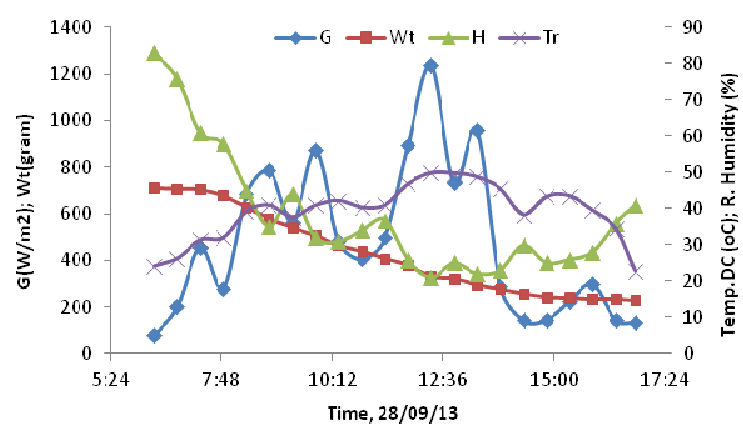

Figure 4: The intensity of the solar radiation, materials Weight, Temperature and Relative Humidity drying chamber, at any drying time.

The weather on Friday and Saturday 27 - 28 September 2013 were not bright shown in Figure 3 and 4 . The solar radiation was not constant during the drying process. On Friday 27 September 2013, the collector plate temperature reaches $101^{\circ} \mathrm{C}$ at $11: 32 \mathrm{a} . \mathrm{m}$. and the highest temperature of drying chamber was $48.1^{\circ} \mathrm{C}$ at $11: 42$ a.m., while the Relative humidity reaches below $60 \%$ at 07:52 am and it continued decrease adn it was constant betwen 30-40 \%. Showed a low relative humidity drying process goes relatively quickly after around 08.00 a.m. In the afternoon, drying process is still going on that shown with the weight loss of rosella flower petals, because the relative humidity in the drying chamber was below $50 \%$ although the drying chamber temperature approaching the ambient temperature that is $32^{\circ} \mathrm{C}$. On Saturday 28 September 2013, the collector plate temperature up to $97^{\circ} \mathrm{C}$ at $12: 10 \mathrm{pm}$. and the highest temperature of the drying chamber is reached $49.9^{\circ} \mathrm{C}$ at $12: 05 \mathrm{pm}$. With the temperature around $50^{\circ} \mathrm{C}$, drying process is very good for agriculture product because the chemicals materials contained such as vitamins and anthocyanins will not damage. Relative humidity reached below $60 \%$ at 7:25 pm and at midday decreased to $20 \%$, this is because the material is dried enough, that water entrained dry slightly, so the water evaporation rate is slow but quickly drop in relative humidity 
and the afternoon at around 4:00 pm humidity is below $10 \%$. Relative humidity within the drying chamber was low, it was possible that additional capacity dried material in the drying chamber, because the diffusivity of water in certain materials.

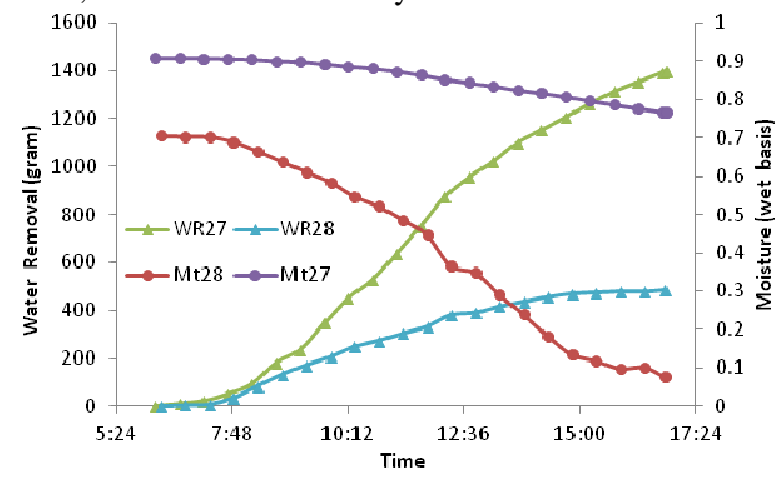

Figure 5: Decrease the humidity of materials and removal of water from the material, during the drying process.

Figure 5 shows that the moisture content of the dried material is initially wet basis and $90.84 \%$ on the first day of drying the moisture content reached $76.67 \%$, while on the second day reached $7.63 \%$. In the evening the moisture content was decrease to $70.42 \%$ or moisture evaporation as much as 190.85 grams. That happened because the relative humidity still low in the afternoon and there was still some heat in the drying chamber (the heat storage in the drying chamber board ), so that the release of moisture run until the relative humidity $80 \%$ was almost the same as the surrounding air. The release of moisture from the material on the first day up dried to 1397.365 grams and on the second day of 482.068 grams, while in the night it was 190.85 grams. The rate of moisture decreased was inversely proportional to the rate of moisture release from the material, from the comparison of the data with the first to two day shows that the release of moisture was also influenced by the moisture content of the material. On the second day after the moisture content below $14 \%$ relative humidity conditions and the material temperature also the moisture content increased slightly, it was because the material at high humidity was suspectible to re-absorption of moisture.

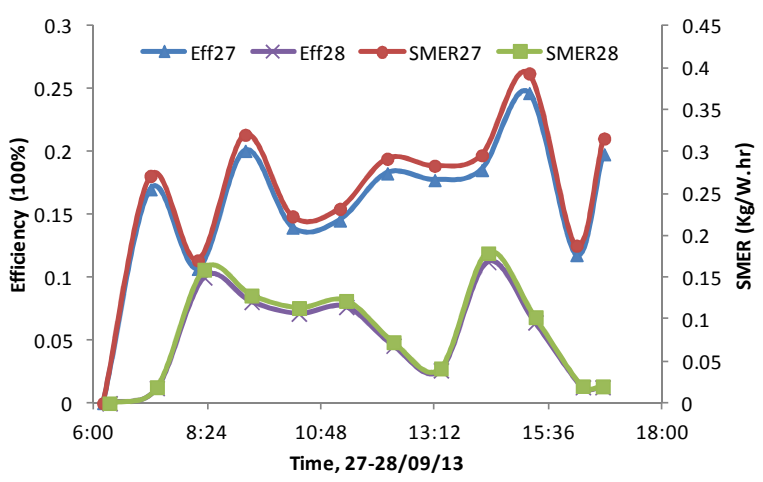

Figure 6: Efficiency and SMER hourly.

Performance of dryer can be detected with thermal efficiency and Specific Moisture Evaporation Rate (SMER) . Efficiency and SMER every hour during the drying process can be seen in Figure 6, the performance of the dryer on the second day is much lower than the first day, although the solar collector was not much different override is $21.12 \mathrm{~kJ}$ on the first day and $18.80 \mathrm{~kJ}$ at the second day, it was because the water content of the material as much on the first day, it can be said that the dryer performance was affected by the moisture content of the dried material or influenced by the amount of water that can be evaporated. Referring efficiency or SMER was still low and the effect of the amount of water to be evaporated on the performance of the dryer, it was still possible increased, or need to vary the amount of load dryers. Daily efficiency on the first day and the second is $14.931 \%$ and $5.78 \%$, while daily SMER on the first day and the second were 0.222 and $0.0256(\mathrm{~kg} / \mathrm{kWh})$

\section{CONLUSIONS}

The weather on Friday and Saturday (27-28 September 2013) was cloudy. The time needed for drying Rosella petals until 7,63\% water content was 2 days, it was much faster than using open drying system. Drying rate became faster after 08.00 A.M with relative humidity under $60 \%$. And on the night the water release process still on going until air humidity was about $80 \%$. On September $27^{\text {th }}$ where water degree inside the material was above $76,67 \%$ with highest drying chamber temperature $48,1^{\circ} \mathrm{C}$ on 11.42 am, and on September $28^{\text {th }}$, material's water degree has lowered with highest drying chamber temperature was $49.9^{\circ} \mathrm{C}$ on $12.05 \mathrm{am}$. That temperature range was good for agricultural product and it was $\mathrm{n}$ damaged chemical substance on the product. Drying $p$ irmance was affected by moisture amount of dried material or by moisture amount that can be hydrated and external factor such as weather. On this research, efficiency on first and second day were $14,391 \%$ and $5,78 \%$ while daily SMER on the first and second day were 0,222 and 0,0256 $(\mathrm{kg} / \mathrm{kWh})$. Drying capacity was still possible to improve or in the next research capacity of the dryer can became variable.

\section{ACKNOWLEDGMENT}

We thank you very much for director general department of education and culture that already defrayed this research with Simlitabmas Program, DP2M, skim Desentralisasi Perguruan Tinggi with classification renewable energy. Thank you also for chairman and staff of LPPM UPN "Veteran" Yogyakarta and university students that already supported this research

\section{REFERENCES}

Akbar, S. A. 2007. Utilization of fermented palm bunches trash combined with defaunation and rumen by pass protein on sheep performance. Journal of the Indonesian Tropical Animal Agriculture 32 (2): 80-85.

Arroyo,S.F., Inmaculada C. Rodríguez-Medina, RaúlBeltrán-Debón, Federica Pasini, Jorge Joven, Vicente Micol , Antonio Segura-Carretero, Alberto Fernández-Gutiérrez, 2011, Quantification of the polyphenolic fraction and in vitro antioxidant and in vivo anti-hyperlipemic activities of Hibiscus sabdariffa aqueous extract, Food Research International 44:1490-1495

Baiq Arie Sudarmayanti dan M. Yunus , 2011, Budidaya Tanaman Rosella (HisbiscusSabdariffa L.) Kan Keunggulannya, http://ntb.litbang.deptan.go.id/ind/index.php?option=com content\&view =article \&id=412:budidaya-tanaman-rosella-hisbiscus-sabdariffa-1-dan keunggulannya \& catid = 53: artikel\&Itemid $=49$, May $12^{\text {th }} 2011,10: 36$

Chua, K. J., Chou, S. K., Ho, J. C., \&Hawlader, M. N. A. (2002). Heat pump drying: Recent developments and future trends, Drying Technology, 20(8) :1579-1610. 
Daniel,D.L., B.E. Barragan Huerta, I. Anaya Sosa, M.G. Vizcarra Mendoza, 2012 , Effect of fixed bed drying on the retention of phenolic compounds, anthocyanins and antioxidant activity of roselle (Hibiscus sabdariffa L.), Industrial Crops and Products $40: 268-276$

Jairaj, K.S ,Singh,S.P., Srikant, K., 2009, A review of solar dryers developed for grape drying, Solar Energy 83: 1698-1712

Lalit M. Bal, SantoshSatya, S.N. Naik, VenkateshMeda, 2011, Review of solar dryers with latent heat storage systems for agricultural products, Renewable and Sustainable Energy Reviews 15 (2011) 876-880

LinaWidawati, 2012, Pengaruh Metode Pengeringan Terhadap Tingkat Kesukaan Teh Bunga Rosela (Hibiscus sabdarifa L), JurnalAgribis Vol. IV No. 1 : xx-XX
Pi-Jen Tsai, John McIntosh, Philip Pearce, Blake Camden, Brian R. Jordan, 2002,Anthocyanin and antioxidant capacity in Roselle (Hibiscus Sabdariffa L.) extract, Food Research International 35:351-35

Sharma, A., Chen, C.R., Nguyen Vu Lan, 2009, Solar Energy Drying Systems: A Review, Renewable and Sustainable Energy Reviews 13 1185-1210.

Singh, S., Kumar,S., 2012, New approach for thermal testing of solar dryer: Development of generalized drying characteristic curve, Solar Energy 86 : 1981-1991 